\title{
Thermal water chemistry of Yellowstone National Park after 24 years of research
}

\author{
D. Kirk Nordstrom ${ }^{1, *}$, R. Blaine McCleskey ${ }^{2}$, and James W. Ball (retired) ${ }^{2}$ \\ ${ }^{1}$ University of Colorado, Boulder, CO 80303 USA \\ ${ }^{2}$ U.S. Geological Survey, Boulder, CO 80303 USA
}

\begin{abstract}
The collection, analysis, and interpretation of 24 years of thermal water chemistry data from Yellowstone National Park have led to substantial insights into the water-rock interactions here and implications for other geothermal areas. New sampling and analytical methods have been developed and tested for trace elements. Quantitative measurements were obtained for changes in redox species of $\mathrm{S}, \mathrm{Fe}, \mathrm{As}, \mathrm{Sb}$, and $\mathrm{Hg}$ during outflow of thermal waters in which biotic and abiotic reactions play important roles. Fluoride speciation calculations were confirmed with ion-selective electrode measurements. The fate of contaminants, especially As and F, from thermal features in major rivers revealed no significant attenuation during downstream transport. Continuous monitoring for heat flux using year-round conductivity measurements was established. Testing of the "Multiple Equilibria Geothermometer" was achieved with high-quality, long-term data from Ojo Caliente, a continuously flowing hot spring. Yellowstone continues to be an outstanding field laboratory for expanding our knowledge of thermal water-rock interactions.
\end{abstract}

\section{Introduction}

Prior to1994, little data was available on redox species in Yellowstone's thermal waters. In collaboration with State University of New York researchers at Stony Brook, the U.S. Geological Survey (USGS) developed techniques for sampling and analysing water samples for thiosulphate and polythionate species in addition to sulphide and sulphate [1]. This program developed further to an investigation of $\mathrm{As}_{\text {III/V }}$ redox species in 1998 combined with routinely collected $\mathrm{Fe}_{\text {II/III }}$ determinations. In 2000, the USGS began collecting samples for $\mathrm{Hg}$ (total dissolved, TDM) and in 2003, methylmercury (MeHg). Collaboration with Wuhan University led to an investigation of measured versus calculated $\mathrm{F}$ species in 2010. Further collaboration with researchers at Wuhan in 2013 led to a comparison of Tibetan geothermal water chemistry with that at Yellowstone. Procedures for measuring $\mathrm{Hg}$ speciation $\left(\mathrm{Hg}_{0}\right.$ and $\mathrm{Hg}_{\mathrm{II}}$ in addition to TDM and MeHg) began in 2015 and results are being prepared. This paper summarizes 24 years of our continuous research on sampling, analysis, and interpretation of Yellowstone's thermal water chemistry.

\section{Methods}

Details of the USGS sampling and analytical methods are published in [2]. Until 2015, vacuum-style samples were collected using a peristaltic pump in silicone tubing to an all-plastic acid-cleaned filter unit with 0.1-micron pore-size filter membranes. Beginning in 2015, a pump-style bladder was used that is required for gases and volatile trace constituents such as $\mathrm{Hg}$. Cations are preserved with ultrapure $\mathrm{HNO}_{3}$ acid; $\mathrm{Fe}^{(\mathrm{II} / \mathrm{III})}$ and $\mathrm{As}^{(\mathrm{III} / \mathrm{V})}$ are preserved in a separate bottle with ultrapure $\mathrm{HCl}$ acid; sulphide is preserved

\footnotetext{
*Corresponding author: dkn@usgs.gov
} 
with sulphide anti-oxidant buffer (SAOB) and measured with an ion-selective electrode (ISE) within 3 days; thiosulphate is preserved with $\mathrm{Zn}$-acetate and $\mathrm{NaOH}$ to remove sulphide; polythionate is preserved similarly to thiosulphate but with the addition of thiocyanate; $\mathrm{Hg}$ is collected separately in an oven-fired glass bottle preserved with $\mathrm{HNO}_{3}$ and dichromate solution or $\mathrm{BrCl}$; and anions are filtered but otherwise kept chilled with no additives. Dissolved sulphide is particularly challenging to measure reliably for thermal waters. The USGS has found the ISE method to be more consistent and reliable than the colorimetric (methylene blue) method. Most thermal waters have detectable sulphide, which mostly converts to volatile $\mathrm{H}_{2} \mathrm{~S}$ and partly oxidizes to thiosulphate, the amount depending on $\mathrm{pH}$ more than temperature. Temperature, $\mathrm{pH}$, redox potential, dissolved oxygen (DO), and specific conductance are measured on site in an insulated flow cell except for DO, which is collected in a Winkler DO bottle and titrated immediately while excluding air. Discharge measurements for rivers were collected along with water samples using conventional flow meters and ultrasonic Doppler flow meters.

\section{Results}

\subsection{Sulphur speciation}

Thiosulphate was found in nearly all hot springs where sulphide was detected, regardless of $\mathrm{pH}$ and temperature, but its concentration was consistently less in acid waters because it disproportionates readily with decreases in $\mathrm{pH}$ [3]. Measurements at the flowing Ojo Caliente spring (Fig. 1) shows the loss of $\mathrm{H}_{2} \mathrm{~S}$ and the increase in DO and thiosulphate.

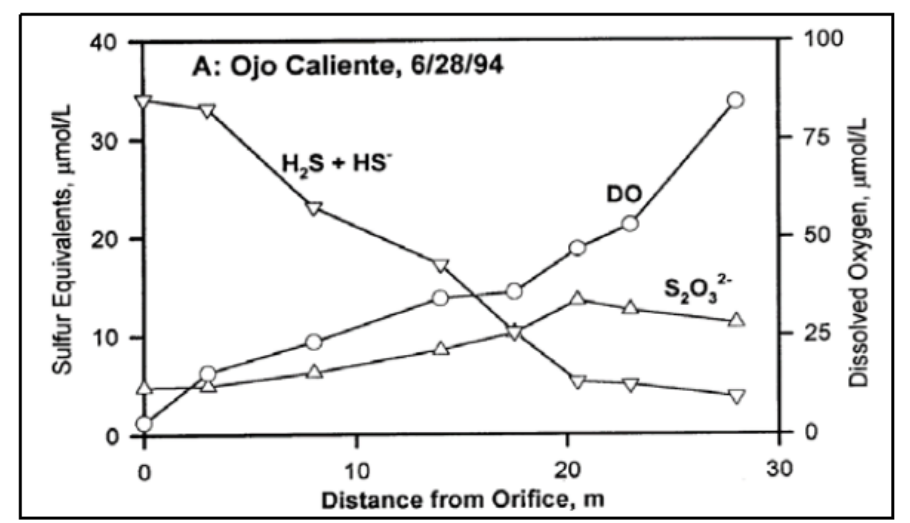

Fig. 1. Change in concentrations of total dissolved sulphide, DO, and thiosulphate for a continuously flowing spring, Ojo Caliente in Lower Geyser Basin [1].

Thiosulphate concentrations range from detection $(<0.1 \mathrm{mg} / \mathrm{L})$ to $70 \mathrm{mg} / \mathrm{L}$ (Evening Primrose) depending on $\mathrm{pH}$, sulphide concentration, and air exposure (surface area and residence time). Large, non-

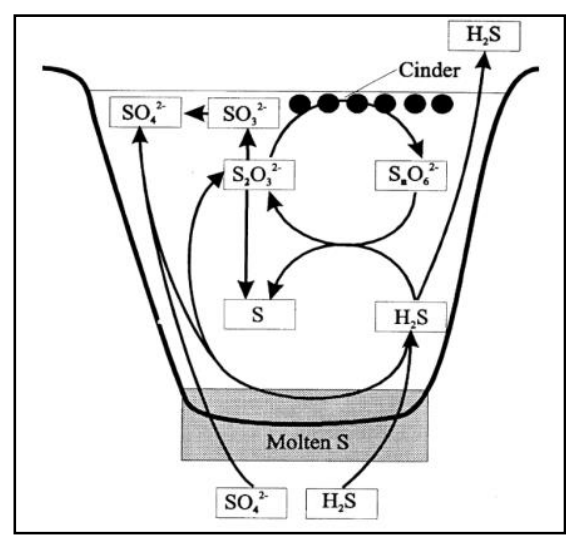

Fig. 2. Schematic diagram for major Scycle transformation for Cinder Pool [3]. flowing pools with continuous gas inflow like Evening Primrose and Cinder Pool will have the highest concentrations of thiosulphate. Cinder Pool is unusual because hot fluids are rising through a molten sulphur layer and producing high concentrations of thiosulphate (Fig. 2). Pyritic decomposition of thiosulphate produces high concentrations of polythionates [3].

\subsection{Arsenic speciation}

Dissolved arsenic range from detection $(\sim 0.0005 \mathrm{mg} / \mathrm{L})$ to 15 $\mathrm{mg} / \mathrm{L}$, although the vast majority of thermal features are in the range of 0.1 to $3 \mathrm{mg} / \mathrm{L}$. Results for $\mathrm{As}_{(\mathrm{III} / \mathrm{V})}$ redox species are highly variable from all $\mathrm{As}_{(\mathrm{III})}$ to all $\mathrm{As}_{(\mathrm{V})}$ with few samples having a comparable mixture. Although arsenic is reduced at depth, arsenic-oxidizing microbes can rapidly convert $\mathrm{As}_{(\mathrm{III})}$ to 
$\mathrm{As}_{(\mathrm{V})}$ and iron-oxidizers can convert $\mathrm{Fe}_{(\mathrm{II})}$ to $\mathrm{Fe}_{(\mathrm{III})}$ when the fluid is contaminated by air at or near the Earth's surface (Fig. 3A and B).

Confirmation of this interesting phenomenon was achieved both in the laboratory and in the field because pyritic spherules cover the pool with different amounts at different times and the larger coverage of "cinders" produces more polythionates and less thiosulphate. When there are very few cinders, the thiosulphate is present at higher concentrations and the polythionates are much lower. This active sulphur cycle also must be buffering the $\mathrm{pH}$ because it has changed very little from 4.2 over 24 years.

$\mathrm{The} \mathrm{As}_{(\mathrm{III} / \mathrm{V})}$ ratio is also dependent on the amount of reduced sulphur remains in the fluid as shown in Fig. $3(\mathrm{C})$. The higher the concentration of reduced sulphur compounds, the more reduced As is likely to be. Sulphide can keep the arsenic reduced but it can also form thioarsenites and thioarsenates [4]. Thioarsenates occur in Yellowstone waters but the sampling and analysis is challenging.

Samples must be flash frozen, and kept frozen until analysed by IC-ICP-MS in an argon-flushed system. Hence, sulphide makes arsenic complexes in aqueous solutions and they will keep the arsenic soluble and mobile.

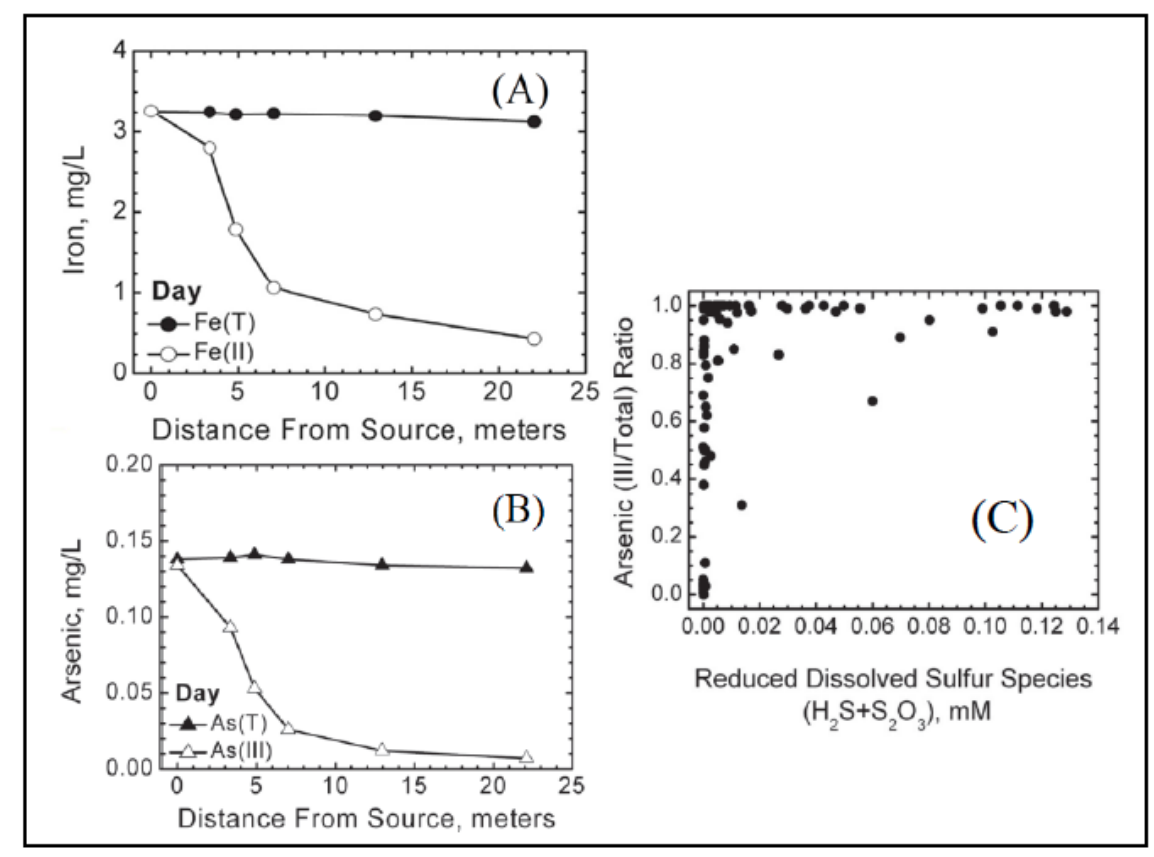

Fig. 3. (A) Oxidation of dissolved Fe $\mathrm{III}_{\text {II }}$ during outflow of Nymphy Creek hot spring. (B). Oxidation of AsIII during Nymphy Creek hot spring outflow. (C) Relation between AsIII/Astotal ratio and the concentration of reduced sulphur species $\left(\mathrm{H}_{2} \mathrm{~S}+\mathrm{S}_{2} \mathrm{O}_{3}\right)$ (modified from [5]).

\subsection{Fluoride speciation}

Speciation calculations for natural water chemistry are based on stability constant data and solving mass action and mass balance expressions simultaneously, but it is not often that speciation calculations can be corroborated by analytical measurement. The F ion-selective electrode (FISE) actually measures the free Fion activity and with the wide range of $\mathrm{F}$ concentration, $\mathrm{pH}$, and potentially complexing ions in Yellowstone's thermal waters, they are ideally suited for a comparison between measured and calculated $\mathrm{F}$ activity [6]. The results were quite good with the range of free $\mathrm{F}$ activity from $<1 \%$ to $>99 \%$ and a pH range of 2 to 10 . Total dissolved $F$ concentration ranges from $<0.1 \mathrm{mg} / \mathrm{L}$ to $48 \mathrm{mg} / \mathrm{L}$. The strongest complexing is with $\mathrm{Al}^{3+}$ and $\mathrm{H}^{+}$as $\mathrm{pH}$ decreases. The species $\mathrm{AlF}^{2+}, \mathrm{AlF}_{2}^{+}$, and $\mathrm{HF}^{0}$ predominate at $\mathrm{pH}<4$. This comparison is only relevant to room temperature because the FISE does not operate at hot spring temperatures. Nevertheless, it gives considerable confidence to our ability to calculate accurate speciation in complex electrolyte solutions. 


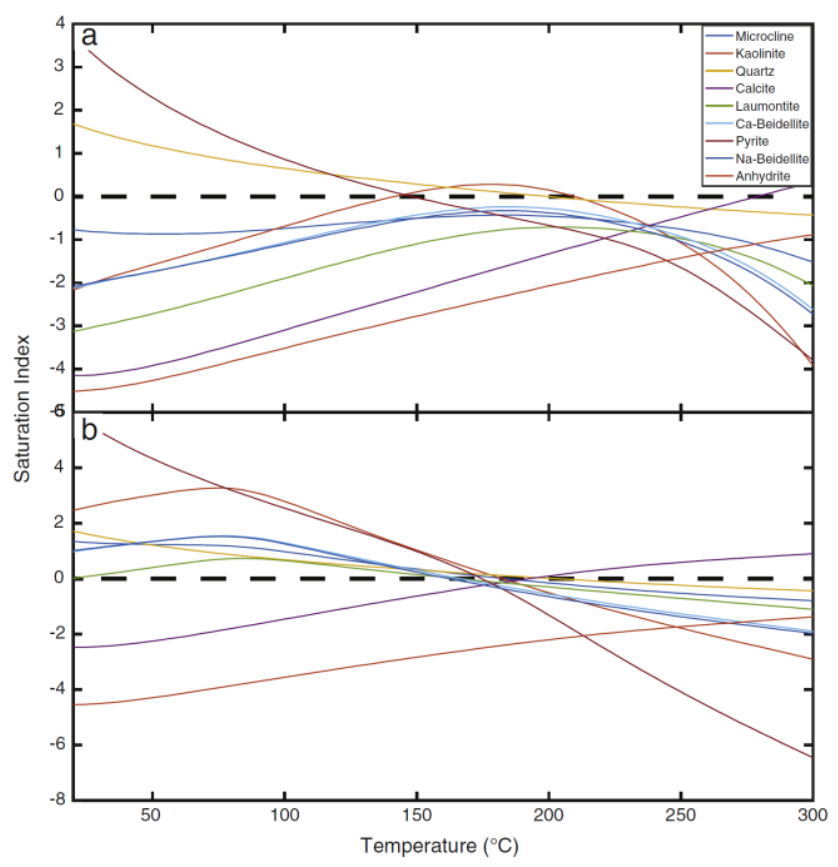

Fig. 4. Saturation indices of a typical hydrothermal mineral assemblage as a function of temperature for a (a) suboptimal and (b) optimized degassing parameters. When degassing estimate is optimized, equilibrium is indicated by convergence of most saturation indices [8].

\subsection{Multiple Equilibria Geothermometry}

Reed and Spycher [7] developed multiple reaction equilibria geothermometry that tests several key mineral reactions for their saturation indices as a function of temperature to find their crossover points, which should represent the equilibrium temperature of the fluid at depth. This model was tested on a set of longterm high-quality USGS chemical data taken from Ojo Caliente over the course of 22 years and has been found to be fairly constant with respect to flow, major ions, but somewhat variable with respect to trace constituents. The objective was to determine the error on the geothermometer results for a set of very highquality analytical data collected over a long time period. The results showed that at Ojo, the equilibrium temperature was $172 \pm 15^{\circ} \mathrm{C}$, which is in excellent agreement with the temperature measured at $88 \mathrm{~m}$ depth in the nearby Y-3 drillhole [8] and the $\mathrm{SiO}_{2}$ geothermometer. Other geothermometers were variable and did not agree as well. Another conclusion was that the natural variability in the chemical composition was greater than the analytical error and the main source of variability is the geothermometry results.

\subsection{Tracking thermal fluids in receiving waters}

Profiles of major and trace constituents in the Firehole and Gibbon Rivers, which receive the largest inflows from hot springs and geysers in Yellowstone, were measured. Gibbon River results are published $[9,10]$, but the Firehole River results are in preparation. Important results from these studies include: (1) nearly all major and trace elements do not show any attenuation during downstream transport over many kilometers distance, (2) the lack of attenuation appears to be silica saturation being reached in the rivers and coating bed sediment with silica that prevents sorptive interaction, (3) redox elements such as $\mathrm{Fe}, \mathrm{As}$, $\mathrm{Sb}$, and $\mathrm{S}$ are rapidly oxidized before reaching the river, and (4) the amount of river flow contributed by the thermal features during low flow periods is about $10 \%$ for the Gibbon River and $30 \%$ for the Firehole River. These discharge results compare well with those of Allen and Day from 84 years ago [11]. Several elements stand out as chemical anomalies in the river because of the large contributions in loadings from thermal features. These elements include $\mathrm{B}, \mathrm{Li}, \mathrm{As}, \mathrm{Sb}, \mathrm{F}, \mathrm{SiO}_{2}, \mathrm{Na}, \mathrm{Cl}, \mathrm{Mo}$, and $\mathrm{W}$. 


\subsection{Tracking thermal fluid over time}

The first analyses of thermal water chemistry from Yellowstone were reported in 1888 [12]. Comparison of those analyses with those made in the last 24 years show very little change in major ion chemistry, particularly in Upper, Midway, and Lower Geyser Basins (inside the caldera boundaries). Although the total water flux over time may be changing, the thermal water chemistry appears to be stable or in a steadystate condition.

\section{Conclusions}

High-quality and repeated long-term measurements of major, trace, and redox-sensitive elements in thermal waters of Yellowstone National Park have revealed rapid oxidation during overflow, lack of attenuation in receiving waters, and a testing ground for speciation and geothermometer computations. Water composition of the main thermal features inside the caldera at Yellowstone National Park seem to have not changed for well over a century. The insights into geochemical reactions at high temperature from the research accomplished at the world's largest hydrothermal field reveal processes that should have substantial benefits for other geothermal area.

\section{References}

1. Y. Xu, et al., Geochim Cosmochim Acta 62, 3729-3743 (1998)

2. R.B. McCleskey, et al., USGS Data (2014)

3. Y. Xu, et al., J Volcanol Geotherm Res 97, 407-423 (2000)

4. B. Planer-Friedrich, et al., Environ Sci Technol 41, 5245-5251 (2007)

5. D.K. Nordstrom, et al., Geothermal Biology and Geochemistry in Yellowstone National Park, 74-94 (2005)

6. Y. Deng, et al., Geochim Cosmochim Acta 75, 4476-4489 (2011)

7. M.H. Reed, N.F. Spycher, Geochim Cosmochim Acta 48, 1479-1492 (1984)

8. J.M. King, et al., J Volcanol Geotherm Res 328, 105-114 (2016)

9. R.B. McCleskey, et al., J Volcanol Geotherm Res 193, 189-202 (2010)

10. R.B. McCleskey, et al., J Volcanol Geotherm Res 196, 139-155 (2010)

11. E.T. Allen, A.L. Day, Hot Springs of Yellowstone National Park, Carnegie Institute of Washington (1935)

12. F.A. Gooch, M.B. Whitfield, USGS Bull 47 (1888) 